\title{
REVIEW OF INTERNATIONAL ARRANGEMENTS RELATING TO OWNERSHIP STATUS OF THE FOREIGN HISTORICAL SHIPWRECKS IN INDONESIAN WATER
}

\author{
Muhammad Nur \\ Faculty of LawnUniversitas Ahmad Dahlan \\ email :muhammad.nur@law.uad.ac.id
}

\begin{abstract}
At the international level there have been international conventions that accommodate the regulation of historic sinking vessels, although only in general, namely the 1982 United Nations Convention on the Law of the Sea (UNCLOS 1982), Convention on the Protection of the Underwater Cultural Heritage 2001, International 1989 Convention on Salvage, and The United Nations Convention on the Means of Prohibiting and Preventing the Mlicit Import, Export and Transfer of Ownership of Cultural Property 1970. However, if you see the contents of the regulation from the international provisions, it seems that there is no firmness regarding the legal owner of the historic sinking vessel in Indonesia. This study uses a normative juridical research method by examining library materials or other secondary materials. The data collection method used is the literature study. The tool used is a document in the form of primary, secondary and non-legal materials. The data obtained were analyzed qualitatively then presented descriptively.
\end{abstract}

\section{Keywords: Review, Historic Sinking Vessels, International Conventions.} \section{INTRODUCTION}

The dominating sea area and its strategic position between the two continents crossing lanes make Indonesian territorial waters crowded by foreign ships. This condition was noted in various historical sources, both the records of European explorers, as well as information from imperial Chinese envoys such as Ma Huan, I Tsing, and Admiral Ceng Ho who stated that since the 5 th century AD Indonesian waters had become international trade shipping lanes. ${ }^{1}$ Ships sailed from the Mediterranean, India and Africa to airports in the waters of the archipelago in search of spices, camphor and gold on the island of Sumatra. The archipelago in the past was known as the country under the wind. This term also refers to an area that has the most expensive and rare types of spices: cloves, nutmeg, and mace. Proven record of explorers from Europe, China, and Arab, the waters of the archipelago is true once the international trade lanes bustling at that time. ${ }^{2}$

Several archives in European and Chinese countries noted that the process of the trading period lasted for hundreds of years. In addition, in the archive reports, it was also noted that many merchant ships sank along Indonesian waters. Historical records and documents say that from the 7th century to the 19th century, the Indonesian waters had become a tomb for sinking ships. They came from Chinese merchant ships (from various dynasties), ships Verenigde Oost-Indische Compagnie (VOC), Dutch, Portuguese, Spanish, English and Japanese. Already thousands of ships have suffered bad luck until they finally wrecked for various reasons, such as: not having the power to face storms

\footnotetext{
${ }^{1}$ Reid, Anthony, 1993, Southeast Asia in the Age of Commerce, 1450-1680, Vol.11, Expansion and Crisis, New Haven, Yale University Press, Page 5.

${ }^{2}$ Turner, Jack, 2011, Sejarah Rempah: Dari Erotisme Sampai Imprealisme, Komunitas Bambu, Depok, Page 29.
} 
and bad weather; lack of knowledge of shipping geographical navigation so that the ship crashes into a reef or is charred; or other causes such as ships being targeted by pirates and / or war. ${ }^{3}$ This statement is getting stronger with data from the Ministry of Maritime Affairs and Fisheries which states that there are around 493 shipwrecks along Indonesian waters containing historic sinking cargo objects. These points are spread from Sabang to Merauke. However, based on data collected by UNESCO, there are more than 3,000 sinking ship points containing valuable objects in Indonesian waters. The large number of shipwrecks suspected of containing historic ship-loading objects will certainly invite various problems, both theft and destruction. Some examples of theft of cultural heritage objects occurred in the case of theft of cultural heritage objects in Cirebon waters from April 2004 to August 2005, as well as cases of theft in 1985, namely the theft of VOC's De Geldermalsen ship which sank in Haliputan waters, Tanjung Pinang. ${ }^{4}$

The results of the analysis found that the boom in search for cultural heritage objects, especially cultural heritage objects found on the seabed as valuable objects sinking ships began when Michael Hatcher (from Australia) discovered the skeleton of the VOC-De Geldermasen heritage ship, which was thought to have sunk 237 years ago, which is 14 miles from the southeastern coast of Bintan Island with the findings auctioned in Amsterdam with a profit of US \$ 17 million. In this case the Indonesian Government accused Michael Hatcher of stealing valuable objects from sunken shiploads (BMKT) from Indonesian waters. ${ }^{5}$ The Hatcher case was horrendous and invited prolonged controversy. His actions in removing objects of cultural heritage illegally, are considered to have harmed the Government and the Indonesian Nation. However, this was denied by the Dutch Ministry of Foreign Affairs which stated that Hatcher's findings took place in international waters. Even claiming that his party was actually the legitimate heir of the sinking ship. The latest and most horrendous event was the capture of a Chinese-flagged vessel Chuan Hong 68, a Grab Hopper type vessel or an 8352 GT weighted dredger on April 28, 2017 at Panggarang Waters in East Johor Malaysia. This ship is thought to be related to stealing valuable objects from sunken shiploads around Natuna and the South China Sea Indonesia, namely Swedish Supertanker Seven Skies (drowned in 1969), Italian Ore / Igara Steamship Oil (drowned March 12, 1973), Japanese warship Permit Sagiri, ship Japanese passenger Hiyoshi Maru and Katori Maru. ${ }^{6}$

The potential of historic sinking ship objects for the Government, of course, can be a significant source of non-tax revenue to the state budget. As for national and foreign private entrepreneurs and investors, it is certainly a very lucrative opportunity. Cultural heritage objects always provide extraordinary charm, because besides being of high economic value, they can also make a tremendous contribution to the development of science, culture and history. But the number of protests against the ownership status, sale and auction of valuable objects as long as the sinking vessel should be of concern to the government, that there are disagreements from various groups, especially countries that have direct links with ships and their cargo if the historical inheritance is claimed by

\footnotetext{
${ }^{3}$ Bambang Budi Utomo, 2008, Kapal Karam Abad Ke-10 di Laut Jawa Utara Cirebon, Panitia Nasional Pengangkatan BMKT, Jakarta, Page 18.

${ }^{4}$ Ibid, Page 30.

${ }^{5}$ Lilik Pudjiastuti and Franky Butar-Butar, Izin Pengangkatan Benda Berharga Atas Muatan Kapal Tenggelam (BMKT) Sebagai Instrumen Konservasi Sumber Daya Laut di Indonesia, Yuridika: Volume 25 No 2, May-August 2010, Page 16.

${ }^{6}$ Ministry of Maritime Affairs and Fisheries Indonesian Republic, FAQ Barang Muatan Kapal Tenggelam (BMKT), open acces at http://kkp.go.id/artikel/2639-faq-barang-muatan-kapal-tenggelam-bmkt, accesed in 21 March 21, 2018 at 3:00 p.m. western Indonesia time.
} 
Indonesian government. Crime against cultural heritage is a crime involving humanity because cultural heritage is a cultural identity of a nation. Illegal trade, smuggling, and the illegal transfer of ownership of cultural objects of a nation can result in a process of cultural impoverishment and disappearance of a nation's identity. Therefore, according to the law on crimes against cultural heritage is not an ordinary crime, but it is categorized as an extraordinary crime. ${ }^{7}$ This paper then attempts to review international arrangements relating to ownership status of the foreign historical shipwrecks in Indonesian water.

\section{ANALYSIS AND DISCUSSION}

\section{Ownership Status of the Historical Foreign Sunken Shipwreck in Indonesian Water.}

The rapid development of various technologies related to the diving sector has impacted on the easier discovery of historic sinking vessels which also led to the sinking of the historic vessel becoming more vulnerable. ${ }^{8}$ One of them is prone to conflict over ownership between the flag state of the ship, its discoverer, the country where the ship sank or the country from which the cargo in it originated. ${ }^{9}$ Various cases of ownership conflicts in fact have occurred in many countries. Not only causes conflict between countries, these cases also become conflicts between individuals, companies and government within a country because of the unclear rules that are the basis for ownership of the historical foreign sunken shipwreck within the country itself.

Unfortunately, based on several provisions of Indonesian legislation governing cultural heritage objects as long as the contents of the ship sank historic, it appears that Indonesia has not been able to provide a fair solution to the conflict. This debate over ownership makes the position of treasure seekers in a difficult place, when faced with claims from the government. ${ }^{10}$ In addition, there are now various movements that demand the concept of a historic shipwreck and its contents as a "common heritage of mankind" which means that the historic shipwreck belongs to all humanity so that it cannot be owned by certain party or country. This movement began to be calculated when President Lyndon Johnson stated "The deep seas and ocean bottoms are, and remain, the legacy of all human beings." These words spoken by President Lyndon Johnson in 1966 foreshadowed an international movement to protect the Oceans. ${ }^{11}$

According to historical records, there have been many cases which show various disputes arising relating to access and control of marine wealth. When the United Nations Convention on the Law of the Sea 1982 was adopted, many people believed that the 50 years of disputes related to the interests of coastal states and countries with maritime powers could be resolved properly. But in reality, this suspicion cannot be said to be true. A new conflict has arisen regarding ownership rights to historic shipwrecks and their cargo. The conflicts of ownership of historic shipwrecks and their contents in the search of the author have occurred several times in various countries. Some of these cases include Sea Hunt Inc. and the Commonwealth of Virginia against The Unidentified

\footnotetext{
${ }^{7}$ See Indonesian Law Number 11 of 2010 concerning Cultural Heritage.

${ }^{8}$ Kusnul Nur Kasanah, 2016, Menanti Kepastian Arah Pengelolaan BMKT, published on the official website of the Cabinet Secretariat of the Republic of Indonesia http://setkab.go.id/menanti-kepastian-arahpengelolaan-bmkt/accessed on September 22, 2018 at 10.30 a.m. western Indonesia time.

${ }^{9}$ David Curfman, 2008, Thar be Treasure Here: Rights to Ancient Shipwrecks in International Waters - A New Policy Regime, 86 Wash. U. L. Rev., Page 181, published in http://digitalcommons.law.wustl.edu/lawreview/vol86/iss1/4 accessed on September 26, 2018 at 10:45 a.m. western Indonesia time.

${ }^{10}$ Ibid.

${ }^{11}$ D. B. Hufford, 1983, Ideological Rigidity vs. Political Reality: A Critique of Reagan's Policy on the Law of the Sea, Yale Law \& Policy Review, Volume 2 Issue 1, Page 127.
} 
Shipwrecked, La Galga and Juno where there was a ownership dispute over a historic shipwrecks between the Commonwealth of Virginia and Spain. Furthermore, there is the case of the Black Swan where there is a dispute between Odyssey, Peru and Spain. In addition there is also the case of Robinson dealing with the Western Australian Museum.

The most controversial case in Indonesia was the case of Michael Hatcher which occurred several times, namely in 1986, 1998, 2010 and 2014. Michael Hatcher was an Australian citizen, who in 1986 hunted historical sinking cargo objects in the Riau Islands without permission from the Indonesian Government. The ship that was hunted at that time was de Geldernmalsen ship which belonged to the Verenigde Oost-Indische Compagnie (VOC) which sank in 1752 . The ship made by the VOC trading company brought valuable commodities such as 100 more gold bars, as well as 20,000 Ming and Ching ceramics which were the result of VOC trade transactions in Nanking China. The results of the hunt for Michael Hatcher produced results that were quite fantastic in number. From the data collected, Hatcher's hunted goods were auctioned at the Christie's Auction Hall in Amsterdam with sales of 17 million US dollars. ${ }^{12}$ However, it is unfortunate that Indonesia does not get a dime of profit from the auction results. In fact, the Dutch government claimed that Indonesia did not have the right to these valuables because the ship was actually owned by the Dutch. The Dutch government seemed unconcerned about the sovereignty of the Indonesian sea area where the ship sank and insisted that the location of the discovery of the ship included international waters.

In 1998, a similar case occurred again by the same person, Michael Hatcher. This time the case took place in the South Sumatra Strait where the historic Tek Sing shipwreck originating from China was estimated to have sunk in 1822 . The results of this appointment amounted to 350,000 valuable objects in the form of ceramics and so on, which were later planned to be auctioned at Nagel Auction Hall, Germany. in 1999. However, the plan was canceled because the German Government had no recommendations from the Indonesian Government. However, in 2000 the auction continued, but the results obtained were not in line with the target, which only produced 3 million US dollars from the target of 30 million US dollars. A total of 1400 remaining unsold ceramics were finally returned to the Indonesian Government.

It hasn't stopped there, in 2010 Michael Hatcher returned to Indonesia to hunt for valuable objects from Ming Dynasty ships that sank in Blanakan waters, Cirebon. Estimated heritage value of the Ming Dynasty is around 200 million US dollars, or nearly equivalent to 1.8 trillion rupiah. However, the action of Michael Hatcher this time was sniffed by the authorities because of public reports that finally Michael Hatcher was banned. Then, on August 3, 2014, information was found that Michael Hatcher was looking for investors to resume the appointment of shiploading objects from the Ming Dynasty on Blanakan Waters. The video on the website (http://www.youtube.com/ watch?v $=$ WC7R2sWdy8Y) proves that Michael Hatcher still has ceramics deposited in Indonesia. In writing, it was mentioned that Michael Hatcher needed money to bribe the government of Indonesia so that the affairs of the project would run smoothly.

Another case, namely the auction of cultural heritage objects raised from Cirebon waters from February 2004 to October 2005 worth 720 billion rupiah also received various opposition and controversy in various circles. Removal of sunken ship cargo objects carried out by Paradigma Putra Sejahtera Ltd, in collaboration with Cosmic Underwater Research Ltd, has actually obtained permission to remove sunken ship

\footnotetext{
${ }^{12}$ Lilik Pudjiastuti and Franky Butar-Butar, Op.Cit.
} 
cargo objects from the Indonesian Government. While the items auctioned at that time consisted of 271,381 pieces, which were 11,000 pearls, 4,000 rubies, 400 red sapphires, and 2200 red agate. The rest are large vases from the Liao dynasty (907-1125M), Yue ceramics from five dynasties (907-960M), Liang Dynasty (907-923), Tang (923-936), Han (947-951), and Zhou (951-960). ${ }^{13}$ UNESCO questioned the activities affecting the Convention on the Protection of Underwater Cultural Heritage. Some people considered that the sale of historic objects seriously hurt the history of the Indonesian people. According to them, history is a part of the past that will determine the future that should not be pawned only for a certain amount of money. The government, in this case

the Ministry of Culture and Tourism, said that they had saved 991 artifacts and had difficulties in providing the place and maintenance costs for the goods, so according to the government it would be better if the goods at the auction were open to the public even for international markets. ${ }^{14}$

The importance of serious efforts to regulate ownership of this historic shipwreck is inseparable from its invaluable existence. Historic shipwrecks, carry the bonds of existence and are evidence of past culture that allows the people involved to enrich their insights about unknown civilizations. Based on this condition, the regulation regarding historic shipwreck ownership and its cargo in Indonesia is very important because with the development of technology, the discovery of historic sinking vessels will also increase. Considering the value of the historic shipwreck and its load is very high, it is a logical consequence that there will be many ownership conflicts over the historic shipwreck and its cargo in the future. At the international level there have been international conventions that accommodate the regulation of historic shipwreck, although only in general, namely United Nations Convention on the Law of the Sea 1982 (UNCLOS 1982), Convention on the Protection of the Underwater Cultural Heritage 2001, International Convention on Salvage 1989, and The United Nations Convention on the Means of Prohibiting and Preventing the Illicit Import, Export and Transfer of Ownership of Cultural Property 1970. However, if you see the contents of the regulation from the international provisions, it seems that there is no firmness regarding the legitimate owners of historic shipwreck objects in Indonesia. A review of the international arrangements is presented in the following explanation.

\section{International Arrangements Relating to Ownership Status of the Foreign His- torical Shipwrecks In Indonesian Water.}

\section{a. United Nations Convention on the Law of the Sea 1982}

One source of international law that regulates shipwrecks and their contents is UNCLOS 1982. This convention itself does not mention shipwrecks and their contents directly but includes objects that have historical and archaeological content. The establishment of UNCLOS itself is a historical event, where this convention is the first agreement of its kind. In addition, the UNCLOS 1982 has been widely accepted in customary law and referred to as a comprehensive marine constitution.

Although UNCLOS 1982 regulates all aspects of the law of the sea, the arrangement of shipwrecks in these two articles is a little vague, namely articles 149 and 303. The provisions of both articles have ambiguous meanings, which do not provide clear general

${ }^{13}$ Ibid, Page 160 .
${ }^{14}$ Ibid. 
guidance. Basically UNCLOS 1982 does not regulate clearly related to the discovery of cultural heritage objects in national and international waters. Article 149 states:

"All objects of an archaeological and historical nature found in the Area shall be preserved or disposed of for the benefit of mankind as a whole, particular regard being paid to the preferential rights of the State or country of origin, or the State of cultural origin, or the State of historical and archaeological origin"

This raises a problem with what is in the interests of mankind and what is meant by objects that have archaeological values and historical values. But these two things are not regulated in the convention. So that the arrangement depends on the interpretation of each country, where the interpretation is of course adapted to the cultural and philosophical background of a country. The ambiguous meanings of article 149 also derives from the privileges of historical and archaeological objects given to certain countries. The limitation of these privileges is not clearly explained and there are no rules when more than one country has that privilege. While Article 303 UNCLOS more generally regulates archaeological and historical objects found in the sea. This article states "States have the duty to protect objects of an archaeological and historical nature found at sea and shall cooperate for this purpose".

The United Nations Convention on the Law of the Sea 1982 generally regulates the protection of underwater culture based on the maritime zone. In the inland water zone, the territorial sea and territorial waters of UNCLOS 1982 regulate that in the country's territorial sea, underwater cultural protection is the jurisdiction of the coastal state. Whereas, in the additional sea zone UNCLOS 1982 did not discuss the ownership of historic shipwrecks, but it was said that foreign vessels could not lift historic shipwrecks without permission from coastal countries that had jurisdiction over these additional lines. Therefore, more specific arrangements will be regulated in the national laws of each country. On the continental shelf, UNCLOS 1982 did not regulate ownership of historic sinking vessels. In the free sea area UNCLOS 1982 regulates all archaeological and historic objects such as historic sinking vessels and their contents are not under the jurisdiction of any country. ${ }^{15}$

Basically, UNCLOS 1982 itself regulates the problem of protecting underwater cultural heritage in the international community in general scope, so that new international legal instruments are needed to specifically formulate the ownership status of the underwater cultural heritage.

\section{b. Convention on the Protection of the Underwater Cultural Heritage 2001}

November 2, 2001, was marked as a very important event for all communities concerned with the protection of culture and underwater archeology, where the general conference of UNESCO approved the Convention on the Protection of Underwater Cultural Heritage with a difficult and complex process. The official negotiations that took place in UNESCO itself, namely for 4 years finally finished.

As a specialized cultural body within the UN system, UNESCO negotiates a special framework on the cultural dimensions of underwater cultural heritage in a different form than the general framework in UNCLOS. In the vast legal structure of the sea and in accordance with the balance of interests contained in UNCLOS, this convention appears as a new general instrument, namely as lex specialis from underwater cultural heritage and its protection, where UNCLOS is the lex generalis of all marine laws.

${ }^{15}$ F. Maes dan T. Derudder, 2014, Assessment of international and European Law Related to or Affecting Underwater Cultural Heritage, IWT SBO PROJECT 120003, Belgia, Page 12. 
UNESCO's initial goal of protecting underwater cultural heritage was more substantial and more extensive than previous international law. The increasing number of destructive activities and looting of underwater cultural heritage implies weaknesses from UNCLOS itself, causing dissatisfaction and creating a new legal regime, the 2001 Underwater Cultural Heritage Convention.

The biggest achievement of the 2001 Underwater Cultural Heritage Convention (UCH Convention) is that this convention is the first universal instrument with a standard of protection against underwater cultural heritage offered to the international community. However, this convention has a number of differences with other international legal doctrines where its effectiveness is still questionable. ${ }^{16}$ One interesting thing about this $\mathrm{UCH}$ Convention is the prohibition of commercial exploitation of underwater cultural heritage. One of the objectives and general principles of this convention is "Underwater cultural heritage shall not be commercially exploited" (Article 2(7) UCH Convention). Furthermore, in the additional section of the convention it describes the rules that must be followed, stating that commercial exploitation of underwater cultural heritage to be traded is not in accordance with the protection and management of underwater cultural heritage. Underwater cultural heritage should not be traded, sold, bought or exchanged for commercial goods (UCH Convention Annex r. 2.). Even this convention does not allow the removal of cultural heritage objects or "in situ preservation". So cultural heritage objects according to the UNESCO Convention may not be moved/contested, because it will cause good damage to the marine ecosystem where the Cultural Heritage Objects are located or to the Cultural Heritage Object itself.

Regulations concerning certainty that cultural heritage objects may be traded are also regulated in one of the articles, namely Article 14 concerning Control of entry into the Territory, Transactions and Ownership, stated:

"States Parties shall take measures to prevent the entry into their territory, the dealing in, or the possession of, underwater cultural heritage illicitly exported and/or recovered, where recovery was contrary to this Convention."

This convention was formed also based on the awareness of the importance of progressive codification and development of rules relating to the protection and management of cultural heritage in accordance with international law and practice. In compromise, this convention allows the storage of restored underwater cultural heritage during the research process (UCH Convention Annex r. 2(b)). However, this storage does not cover the sale of every item that includes underwater cultural heritage. Therefore, the result of the ban on commercial exploitation is an attempt to eliminate commercial motives in commercial companies in an effort to save shipwrecks. So, if this convention becomes international customary law, the consequences of the prohibition of commercial exploitation will be an attempt to destroy the shipwreck rescue industry.

This Convention requires states parties to work together to protect underwater cultural heritage, preserve underwater cultural heritage for the benefit of humanity, and take necessary steps to protect underwater cultural heritage based on international conventions and laws. However, this convention does not expressly regulate ownership rights of historic sinking vessels.

Proponents of this convention believe that this convention opens up the possibility for efforts to save the wreck if it is truly in danger. Article 12 of this Convention allows all

${ }^{16}$ David J. Bederman, 1998, Historic Salvage and the Law of the Sea, University of Miami Inter-American Law Review, Page 140.

38 IUS Kajian Hukum dan Keadilan 
States Parties to make practical efforts to prevent harm to underwater cultural heritage, whether arising from human activities or other causes (Article 12(3) UCH Convention).

"All States Parties may take all practicable measures in conformity with this Convention,

if necessary prior to consultations, to prevent any immediate danger to the underwater cultural heritage, whether arising from human activity or any other cause including looting."

Indonesia itself as the largest archipelagic country in the world with the largest number of shipwreck sites, has not ratified this convention. The decision to ratify or not really needs to be studied in depth for its benefits to national interests, because there are consequences that must be borne, such as: stop the licenses that have been issued including returning to investors all costs incurred in the framework of licensing; compile a road-map/action plan for managing underwater cultural heritage; preparing all supporting facilities and infrastructure including the management institutions, such as training centers, maritime museums, and human resource development; and harmonization of laws and regulations related to historic shipwrecks to be adjusted to the provisions of the 2001 UNESCO Convention.

\section{c. International Convention on Salvage 1989}

In 1989, the International Maritime Organization (IMO), a special body of the United Nations, was tasked with creating arrangements for ships, and then they came to a result, the 1989 International Convention on Salvage. ${ }^{17}$ This Convention replaced Brussels Convention on Salvage in 1910, which did not regulate any provisions regarding historic shipwrecks.

This Convention has different arrangements for underwater cultural preservation, where this convention focuses on efforts to save shipwrecks and their contents in a more specific scope than other conventions. So this convention is different from the convention previously explained which only regulates the protection of shipwrecks and their contents for the benefit of mankind without clearly regulating rescue efforts. Rescue efforts are intended as actions or activities to help ships and their cargo in danger (Article 1(1) International Convention on Salvage 1989).

Provisions in this convention regulate compensation for salvers who have succeeded in recovering shipwrecks and their contents (Article 12 International Convention on Salvage 1989), the criteria for providing rewards (Article 13 International Convention on Salvage 1989), and providing special benefits (Article 14 International Convention on Salvage 1989). This convention has the term no cure, no pay, which means salvor will only be given an award or reward for the service of finding a wreck, in other words if the recovery effort is successfully carried out. This convention also regulates the provision of special rewards, namely if salvers make efforts to prevent pollution in the marine environment but fail to make a rescue effort, this convention provides little compensation for the salvor, although it has little success in recovering the wreck and its cargo. However, there are weaknesses in this convention, because this convention is not considering the arrangement of ownership claims from the sinking ship flag state.

\section{d. The United Nations Convention on the Means of Prohibiting and Preventing the $I$ - licit Import, Export and Transfer of Ownership of Cultural Property 1970}

${ }^{17}$ Brian F. Binney, 1990, Protecting the Environment with Salvage Law: Risks, Rewards, and the 1989 Salvage Convention, Washington Law Review, Vol. 65, No. 3, Page 647. 
In the international context, the United Nations has a series of agreements that regulate the rules of restoration, the return of objects of cultural heritage that are taken illegally abroad, about copyright, and so on. One of them is a convention with No.11806, namely the Convention on the Prohibiting and Preventing the Illicit Import, Export and Transfer of Ownership of Cultural Property which can be ratified by countries to strengthen efforts to protect their cultural resources. This international convention was approved by UNESCO at the XVI general assembly in Paris on November 14, 1970, and this convention came into force on April 24, 1972. The Convention which consists of 26 articles at length defines various matters relating to cultural property that deserve to be protected, both from a historical, archaeological, artistic and scientific point of view. Arrangements regarding ownership of cultural and historic objects such as sinking vessels according to this convention are subject to the enactment of national laws of each country. In this convention, the transfer of property rights, imports, export of all cultural property rights covered by existing definitions, are not directly prohibited. Each state party that recognizes or ratifies this convention must establish its operational rules that affect the property rights of cultural heritage in its territory, and determine between legal and illegal.

The definition of cultural property in this convention covers broader categories including rare flora and fauna specimens, property rights related to history, ethnological objects, property rights with artistic interests, manuscripts, books, documents and old publications, stamps, household furniture, and so on. As for those specifically related to cultural heritage objects as referred to in Article 1, namely:

a. products of archaeological excavations (including regular and clandestine) or of archaeological discoveries;

b. elements of artistic or historical monuments or archaeological sites which have been dismembered;

c. antiquities more than one hundred years old, such as inscriptions, coins and engraved seals;

So, some of the categories of cultural property that must be protected include official archaeological or illegal/illegal excavation products or archaeological findings. In addition, there are elements of art or historical monuments or fragmented archaeological sites and over a hundred years of antiques such as inscriptions, coins and engraved stamp. The arrangement of this convention is also basically limited to efforts to prevent illegal transactions against export-import of cultural heritage objects. Regulations related to who is entitled to historic sinking ship ownership and their contents at this convention are subject to the application of national law where the ship is wrecked.

To provide a solution to the problems that occur and as a precautionary measure, the authors suggest the following:

1. The Indonesian government needs to conduct negotiations with the flag states and the inventor of the historic shipwreck to provide certainty over claims of ownership of cultural heritage objects.

2. The Indonesian government needs to revise the Cultural Heritage Act Number 11 of 2010 by integrating all laws and regulations relating to the preservation of underwater cultural heritage, and provide an opportunity to compromise cooperation and profit sharing on ownership and management of cultural heritage objects.

3. To overcome the problems regarding underwater cultural heritage, Indonesia needs to immediately ratify the Convention on the Protection of Underwater Cultural Heritage. 
4. The Indonesian government, through the relevant ministries, must immediately find the location of underwater cultural heritage and in stages by collaborating with ship flag countries and then establishing it as a cultural heritage site.

\section{CONCLUSION}

Based on the description of the discussion above, the author concludes that conflicts over ownership of valuable historical shiploads of goods occurred between the flag state of the ship, the discoverer, the country where the ship sank or the country of origin of the ship's cargo. This debate over ownership makes the position of treasure seekers in a difficult place, when faced with claims from the government. In addition, there are now various movements that demand the concept of a historic shipwreck and its contents as a "common heritage of mankind" which means that the historic shipwreck belongs to all humanity so that it cannot be owned by only one party or country only certain. At the international level there have been international conventions that accommodate the regulation of historic sinking ships, although only in general, namely the United Nations Convention on the Law of the Sea 1982 (UNCLOS 1982), Convention on the Protection of the Underwater Cultural Heritage 2001, International 1989 Convention on Salvage, and The United Nations Convention on the Means of Prohibiting and Preventing the Illicit Import, Export and Transfer of Ownership of Cultural Property 1970. However, if you see the contents of the provisions of the international provisions, there is no firmness regarding the legal owner of historic shipwrecks in Indonesia. In addition, some of these conventions have not yet been ratified by Indonesia.

\section{REFERENCES}

\section{Books}

Anthony Reid (ed.). (1993). Southeast Asia in the Early Modern Era: Trade, Power, and Belief. Ithaca-London: Cornell University Press.

Bambang Budi Utomo. (2008). Kapal Karam Abad Ke-10 di Laut Jawa Utara Cirebon. Jakarta: Panitia Nasional Pengangkatan BMKT.

David J. Bederman. ,(1998). Historic Salvage and the Law of the Sea, University of Miami Inter-American Law Review.

F. Maes dan T. Derudder. , (2014). Assessment of international and European Law Related to or Affecting Underwater Cultural Heritage. Belgia: IWT SBO PROJECT 120003.

Louis B. Sohn \& John E. Noyes. (2004). Cases and Materials on The Law of the Sea 2nd ed. Leiden, Netherlands: Transnational Publishers Inc.

Turner, Jack. (2011). Sejarah Rempah: Dari Erotisme Sampai Imprealisme. Depok: Komunitas Bambu.

\section{Journals}

Brian F. Binney. Protecting the Environment with Salvage Law: Risks, Rewards, and the 1989 Salvage Convention. Washington Law Review, Vol. 65, No. 3. 2009.

D. B. Hufford, (1983), Ideological Rigidity vs. Political Reality: A Critique of Reagan's Policy on the Law of the Sea, Yale Law \& Policy Review, Volume 2 Issue 1.

Lilik Pudjiastuti dan Franky Butar-Butar. Izin Pengangkatan Benda Berharga Atas 
Muatan Kapal Tenggelam (BMKT) Sebagai Instrumen Konservasi Sumber Daya Laut di Indonesia. Jurnal Yuridika: Volume 25 No 2, May-Auguts 2010.

\section{Internet}

David Curfman, 2008, Tharbe Treasure Here: Rights to Ancient Shipwrecks in International Waters - A New Policy Regime, 86 Wash. U. L. Rev., Page 181, published in http:// digitalcommons.law.wustl.edu/lawreview/vol86/iss1/4 accessed on September 26, 2018 at 10.45 Yogyakarta Local Time.

Kementerian Kelautan dan Perikanan Republik Indonesia, FAQ Barang Muatan Kapal Tenggelam (BMKT), published in http://kkp.go.id/artikel/2639-faq-barangmuatan-kapal-tenggelam-bmkt accessed on March 21, 2018 at 15.56 Yogyakarta Local Time.

Kusnul Nur Kasanah, 2018, Menanti Kepastian Arah Pengelolaan BMKT, published in http://setkab.go.id/menanti-kepastian-arahpengelolaan-bmkt// accessed on September 22, 2018 at 10.30 Yogyakarta Local Time.

\section{Regulations}

Convention on the Protection of the Underwater Cultural Heritage 2001.

Cultural Heritage Law Comm., International Law Association, Buenos Aires Draft Convention on the Protection of the Underwater Cultural Heritage 1994.

International Convention on Salvage 1989.

The United Nations Convention on the Means of Prohibiting and Preventing the Mlicit Import, Export and Transfer of Ownership of Cultural Property 1970.

United Nations Convention on the Law of the Sea 1982 (UNCLOS 1982).

Indonesian Act No. 11 Year 2010 about Cultural Heritage.

Presidential Decree No. 12 Year 2009 about the National Committee for Lifting and Use of Valuable Objects of the Sinking Vessel. 